\title{
A new type of architecture exhibition
}

\section{Empathies between Mackintosh and Holl in Glasgow}

\section{The architecture exhibition reimagined}

The Sensing Spaces: Architecture Reimagined exhibition at the Royal Academy (RA) (arq 18.1, pp. 85-87) was refreshing. It set out to be so and, as far as I could see, succeeded. Its ambition was to redefine the presentation and content of an architecture exhibition. In the teacher's and student's guide available free with entry (and at a nominal cost to others), the RA set out their purpose: 'a new type of architecture exhibition [...] an approach that highlights not the functional but the experiential aspects of architecture, it features the work of seven of the world's leading contemporary architectural practices'. These practices, each of whom contributed installation pieces set within the Beaux-Arts galleries of the RA, were Grafton Architects (Ireland), Diébédo Francis Kéré (Burkina Faso and Germany), Kengo Kuma (Japan), Li Xiaodong (China), Pezo von Ellrichshausen (Chile), Álvaro Siza and Eduardo Souto de Moura (Portugal).

Each of these architects approached some of the fundamental aspects of architecture - history, public participation, place, light, sensuality, movement, for example - in varying degrees and combinations, but I would say with an unusual degree of intelligence and sensitivity. Until quite recently, nineteenth-century architecture was dismissed as terribly bourgeois by architects, but now the combination of strongly geometrical and axial spaces and decoration seems, at least, a respite from contemporary thoughtless and trashy buildings, and it is good that these attributes are acknowledged rather than rejected by architects, as if further alienation from public (rather than populist) discourses was desirable. Some work - that of Diébédo Francis Kéré, for example - was highly participatory and openly 'pop': scores of children were waving plastic fronds on my visit. While that of Eduardo

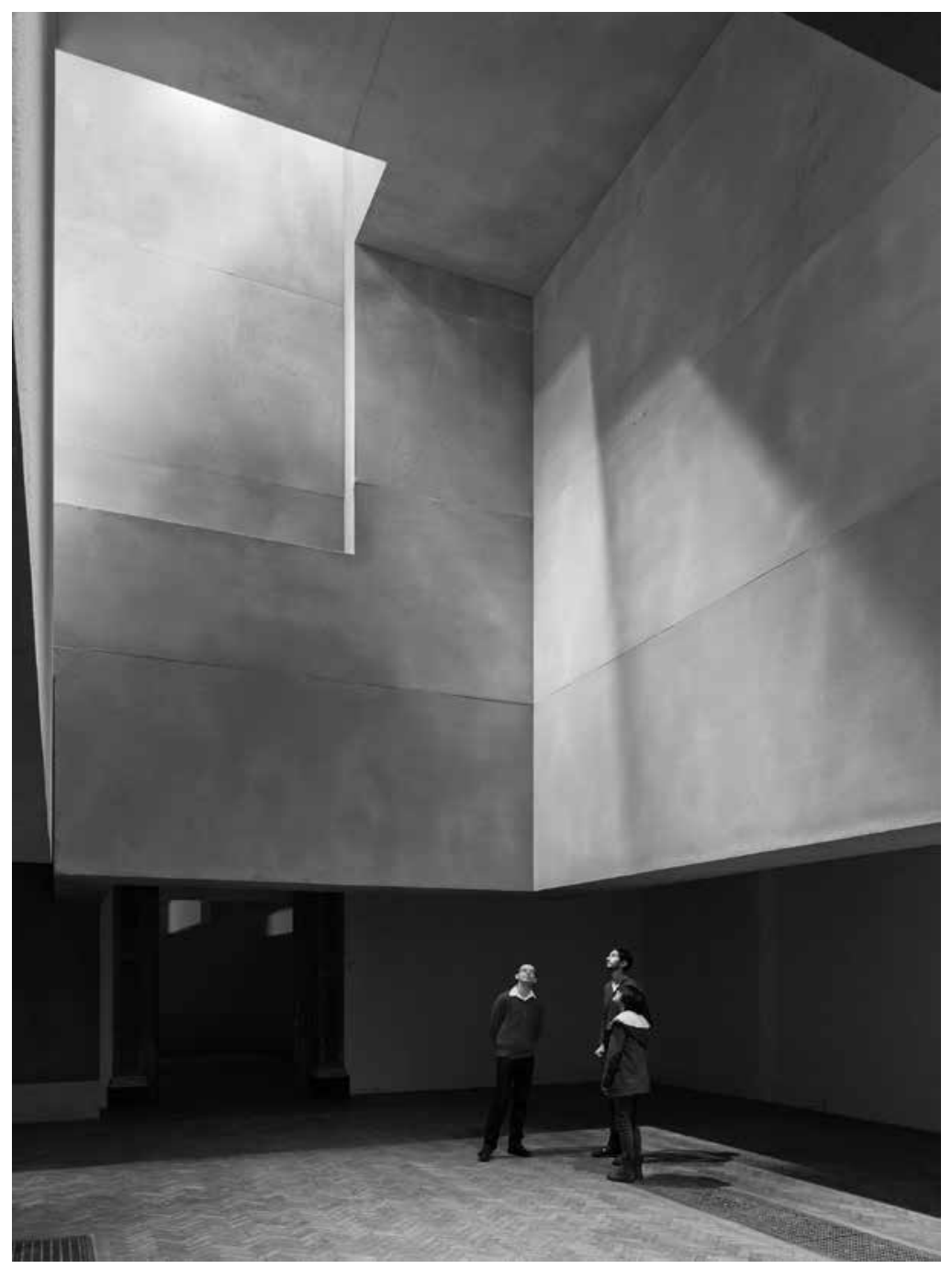

1 Visitors immersed in Grafton Architects' 'weighty' installation
Souto de Moura - door linings replicated in cast concrete and placed adjacent to the original austere. Kengo Kuma's rooms - two dark spaces with an illuminated bamboo lattice - were highly sensual; the fugitive nature of the scent matched the ethereal opening - was cerebral and 


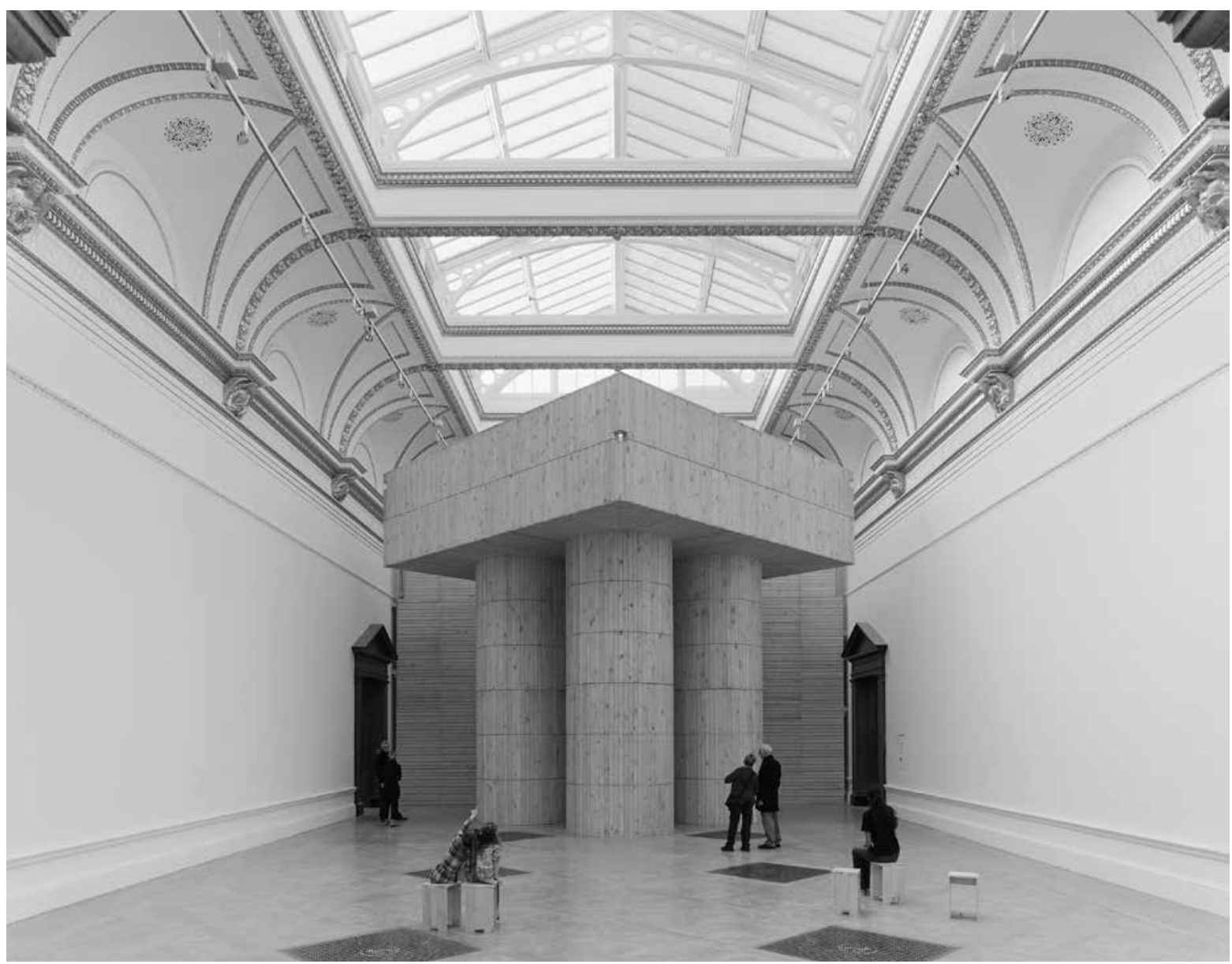

2 The journey through the gallery space curated by Pezo von Ellrichshausen

spaces formed by the bamboo webs. Li Xiaodong seemed to be creating a vernacular space of bamboo screens, guiding visitors though a spatial experience. The work of Grafton Architects was entirely suspended from the ceiling, and they had thoughtfully included benches as part of their installation to allow visitors to gaze up at it. People will choose their own favourites according to their own interests.

The installations were supported by a looped video of other, built, work by these architects and of these architects talking about their work, a common feature of architectural exhibitions in which, generally, the work itself (rather than photographs or models) is not on show. We could see the wonderful cast concrete tower houses and studio on the coast of Chile by Pezo von Ellrichshausen, and the decidedly 'non-pop' but still participatory school in Burkina Faso by Diébédo Francis Kéré, and admire the sensitivity to place inherent in the installation by Grafton Architects.

Sensing Spaces: Architecture Reimagined makes an interesting comparison to art exhibitions on the one hand and to conventional architecture exhibitions on the other. When I went there I saw in no particular order - families of mother, father and toddlers (in various combinations) on a family programme, well-dressed mothers and daughters who may very well have been up from the home counties for an exhibition and shopping, various couples in their twenties and thirties, frequently holding hands and thus a few years from the toddler phase, retired couples and one well-dressed middle-aged man with a Leica M (a M240, the latest very expensive digital model). All of these people (except the toddlers, who were drawing) were taking photographs, on - in a totally unscientific poll - smartphones, DSLRs, and the lone Leica $\mathrm{M}$.

Photography in museums has become a contentious issue. The ease and prevalence of smartphones threatens to destroy the space of art itself. It raises a question: are people looking at the exhibits, or are they looking at themselves looking at the exhibits? Surely that is not what the purpose of publicly funded galleries is? A quick search of online media and museum associations shows broadly that curators are in favour as photography can bring in visitors, while visitors are against it because it disrupts the viewing experience. I'm with the visitors on this, except in Sensing Spaces photography seemed to have been an important part of the experience. Visitors could record the work themselves and thereby record, in some modest way, the relevance of the architecture to their own experiences.

The idea has distinguished antecedents, especially in the work of Bruno Zevi - copiously acknowledged - and Christian Norberg-Schulz - unacknowledged: In reframing the established form of an architectural exhibition, Sensing Spaces extends the focus of Bruno Zevi's writing even further. Following Zevi's principles, what lies at the heart of this exhibition is the desire to help visitors 'reimagine' architecture; a desire founded on the premise that the 'true riches of meaning' in architecture are largely misunderstood, being based on a superficial reading of the art form. This is not to say that exhibitions that present the measurable and theoretical efforts of architects and how these relate to the buildings they produce, do not have their place. It would be nonsensical to argue 
against the fact that background knowledge augments appreciation. This quite clearly is not the only form that an architectural exhibition can take, but it seems to fulfil a void among the public and, possibly, among architects as well. I am reminded of student 'construction' projects that, while quite worthy, are focused on 'making' and miss the point of architecture as a more complex interaction with, for example, place. These installations might be considered a rebuttal against that simplistic notion. There are many questions that we can ask of architecture, but how much a building weighs is surely of very limited interest, if any at all.

THOMAS DECKKER London

Thomas Deckker is an architect based in London and Fellow of the Geddes Institute for Urban Research, The University of Dundee

\section{Less obvious empathies: on Holl and Mackintosh}

The composer of Nixon in China, John Adams, spoke of the work of composer Steve Reich as follows:

There are periods in all the arts when the language reaches a certain critical mass of complexity, beyond which lies only sterile mannerism. At those times, when the art form seems particularly inflated and prolix, spring-cleaning is in order [...] The simple gesture is the hardest of all to defend [...].

In considering Steven Holl's new Seona Reid Building at the Glasgow School of Art (GSA) in relation to Charles Rennie Mackintosh's art school opposite (see arq 17.1 pp. 21-36 and 'Letters' arq 17.2 pp. 101-05) two themes emerge. The first concerns the idea of an architecture of uncertainty as a metaphor for where we are as a society and as a profession: not simply doubt, but the indefinite. The second concerns how we place architecture and architects in a wider contemporary cultural context. Starting with the latter, to attempt a placing of Holl in an American artistic cultural context, in his Reid Inaugural Lecture he plainly set out a lifetime of collaboration with contemporary artists empathetic to his approach. Another architect, his Finnish collaborator, Juhani Pallasmaa suggests that 'Steven Holl resensualises space, material [and] light'. Interestingly motivations may be better understood by shifting outside the visual arts to look at counterparts in music such as Steve Reich.

In 1976, as Holl was completing postgraduate work at the AA and setting up his New York office, Reich launched his music for eighteen musicians based on cycles of eleven chords. Further thoughts on the work of Reich from the artist Richard Serra (which I quote at length) suggest that there may be parallel streams across art forms:

There emerge, at various times and places, manifestations of art which transform the realm of possibilities [...] Let me try to explain what I mean by a rethinking of form in relation to Steve's early pieces, where he uses prerecorded language. He starts out with a seemingly simple premise: a found voice, a sentence uttered. But as he subjugates this found language to his structure of overlays, as it is repeated again and again, the detail of the detail begins to resonate. I find that I am drawn into the infinitesimal, the infinitely subtle moving variations. It's then I realise I am lost in the infinite vastness of the whole. As the voices spin out they become something other than language. The words are transformed by rhythm into emotion. Language is being pushed to the breaking point, where the meaning of the word has been obliterated so as to allow its potential for music to emerge. It's as if the original word or phrase has been stretched along an abstract, infinitely variable line dissolving its original meaning in a process, which allows for a new meaning to emerge.

Thinking of an architecture of uncertainty, I was reminded of the maxim from the RIBA in the early 1970 under president Alex
Gordon - Long Life; Loose Fit; Low Energy - however the idea of the 'grain' or 'pitch' of a building has a significant resonance in the architecture of Steven Holl Architects. There is not the adaptability that might be implied in any ordinary concept of flexibility but an ability to absorb 'change', to absorb life rather than adapt to it: a robustness that has much of the lineage of the Mackintosh building in its DNA. Not rational enough to be mistaken for work following Louis Kahn, but I would like to think it also captures the paradox in the essential permanence of his doctrine on the institution. Yet that lack of concern, or even deliberate avoidance, of any requirement to predict or to specify, a particular interest of both Holl and his partner on this project Chris McVoy, seems to me to be embedded in the Reid Building. When we examine capacity for change it must be recognised that change can be accommodated by adaptation; or by absorption. Cedric Price's Fun Palace and its built manifestation the Pompidou Centre in Paris are examples of the former; yet surely Mackintosh's building itself is a perfect example of the latter. In over 100 years not much has been moved, yet the 'robustness' of the building has produced the longevity capable of accommodating shifts in society, in education and in trends in art: William Simpson, Benno Schotz, Steven Campbell, Douglas Gordon, Toby Paterson. I think the design team have understood exactly how the GSA has been used by students over the last century

Neither is this robustness

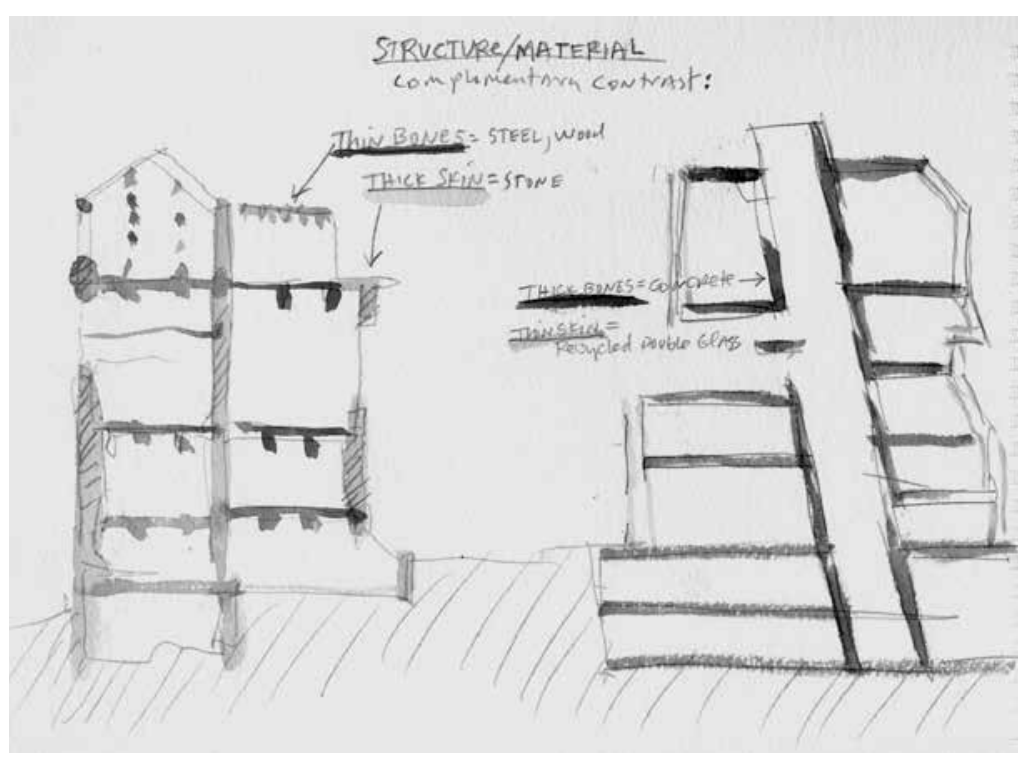

3 Steven Holl, Glasgow School of Art, sketch conveying 'complementary contrast', 2010 


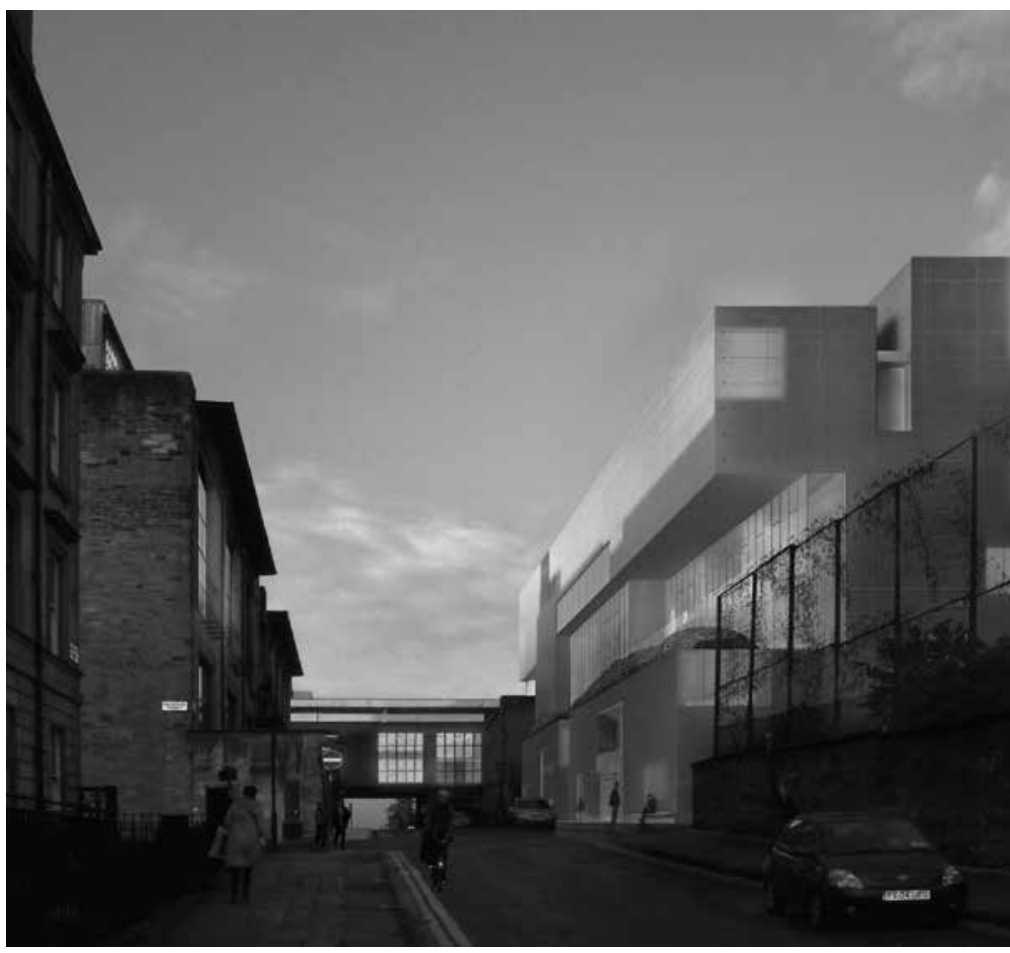

4 Steven Holl, Glasgow School of Art, visualisation as seen from Renfrew Street, 2011

simply a facet of durability, it is the capacity by which the plan and section can take up shifts from the user, offering a multiplicity of possibilities in use. James Stirling, who absorbed the writings of Le Corbusier and for whom the section was the allimportant generator of form - a thesis best exemplified in the four university projects at Leicester, Oxford, Cambridge and St Andrews - observed that all built form has height and properties of stability dependent upon shape, and the necessity in making a grouping of accommodation that is inherently stable. The disposition of forms at Leicester - the tower counterbalanced by the lecture theatre - is a case in point. No doubt there is an architectural quality inherent in the composition of stable images particularly when they are asymmetrical. The 'balance' in the Steven Holl Architects section, developed by partner Chris McVoy, is particularly apparent when viewed as part of the overall cross-section of Renfrew Street with the Mackintosh building: the 'Elbow' in the light tubes, the recess enveloping the Machar, the roofscape. There is also a semiology emanating from the building from a distance. Glimpsing it from the M8, the voids coming through the top are as La Tourette close up yet, from a distance, the building geometry reads as an engine block displaying the triple carburettors of a dragster. Enclosed, the form sleek with all the power hidden under the bonnet.

The idea of a rich spatial over the life of the building corresponds to another aspect of the spaces of the building, the agora. Apple co-founder and chairman Steve Jobs was a strong believer in face-to-face meetings:

There is a temptation in our networked age to think that ideas can be developed by email and $i$-Chat. That's crazy. Creativity comes from spontaneous meetings, from random discussions. If a building doesn't encourage that you'll lose a lot of innovation and the magic that is sparked by serendipity.

Perhaps the finest building where I have witnessed architecture in service of serendipitous face-to-face meetings was in Günter Behnisch's Bonn Parliament building where, as in the Reid Building, a luxurious slow rise on huge wide stairways, lots of them, and break-out space with seating close by encourages people to stop and converse rather than just say 'hello' and move on. The chance encounter here is everything. The Reid Building's central street on all levels reminds me of a small medieval Italian hill town where we turn back on ourselves looking up and down at fellow travellers. The degree to which diagonal movement is emphasised through the building is also Corbusian. But the internal forms don't quote, they hint at might suggest a Shelby Mustang sequence that can take change more complex origins. I also observed the joy in the way in which the light penetrates the studios making inspirational and uplifting spaces. It took me a while to work out where I had seen it before: Abruzzo, where in the film The American we see the full force of that idea. The name Castel del Monte is from the Latin Castellum Montis, meaning 'fortress of the mountain'. Possibly a source. But the central routes that wind up through the building, and the spaces revealed and then reinforced by the voids, capture that spirit. In the enclosure, we see what Pallasmaa identifies as 'a new orientation towards glass. Instead of a perfection and abstraction appealing only to our eyes these buildings provide a sense of matter and craft and the touch of the human hand [...] opacity and depth is often replaced by the enmeshing and layering of translucent, perforated and transparent surfaces'. He then goes to the heart of any analysis of recent Steven Holl Architects' work:

Glass is the material of the alchemist and the magician [...] Glass curiously unifies the four ancient elements by being born of earth and fire and resembling air and water. As a consequence glass acquires cosmic and metaphysical qualities [...] transparency transforms into reflection, immateriality into mass, light into darkness.

Nelson Atkins and much of the recent work of Steven Holl Architects, which both Holl and McVoy have developed, is about illusion and artifice: the metaphysical that, for the architects among us to see it under construction, is to see behind the curtain, to witness the puppet-master or conjuror at work. The immateriality into mass remains immaterial. Yet in its completed state the paradox of the high degree of solidity of something massive wrought from glass is apparent. Here it captures the essence of the Mackintosh building.

Part of Glasgow's signature the point of departure from its sister, Chicago - where it aligns more with San Francisco, is the topography of the drumlins that enclose the northern edge of the city and over which the grid moves relentlessly - Gilmorehill, Park, Garnethill, Dundashill, Rottenrow - creating rich diverse pockets within the city. Isolated from the hinterland by the M8, the Garnethill site was initially a backwater to Sauchiehall 
Street: unknown, unloved and deteriorating, but since the mid 1980 seshaped and reinvigorated. Our office first moved there, to Hill Street, in 1979. Sympathetic in its completeness, the grid accommodates change and subtleties in the major and minor keys: the streets and the lanes. In both Renfrew Street and the original Rottenrow, in the east of the city, simple tenemental forms mitigate or even ignore that topography with cultural buildings knitted into this fabric, including a synagogue, galleries (McLellan), church and school (St Aloysius+ Barony) and even a maternity hospital (Rottenrow).

It is not often that an architect is provided with a whole city block to redevelop but in doing so the scale, rhythm and proportion of the form needs to address that. The Reid Building is no different. It responds to its position just off the peak of one of the city's highest drumlins and it catches an almost uninterrupted construct of north light while its opposite aspect draws in the changing southern light, which in turn is absorbed and altered by the glass on the facade. Holl has an advantage over Mackintosh in a prescribed city block, the lane separating it from St Aloysius. Mackintosh was designing in a tenement block with an indeterminate southern aspect only certain about the roofscape (the so-called 'Hen Run') and the later western return gable. Early maps of the city show villas along this stretch of Sauchiehall Street and the later 'lanes' of the town houses which now can be seen exemplified, as they run through the atrium of the CCA; the evidence of a rich grain of tenemental forms as Garnethill expanded. The shifts in scale at the more mature end of the original GSA Building shows where it is at its most skilful in using the fall in the ground to emphasise the mass of the building. Unlike the original half which could easily have been placed in the gap in the tenement form, complete with rear courtyard, this is a building in the round - almost. It is a tower when viewed from Sauchiehall Street and emphatically so on its return end reinforced by setting glass into the carved solids. The mass dominates rather than the glazing. This topographical device was employed by much later by F. Feilden (Walker \& Cunningham) in 1967 in the new Architecture Building at University of Strathclyde where a three-storey building placed just off the brow of the hill achieves the drama and grandeur of a much taller building when approaching Rottenrow up the steep slope that is North Portland Street. At GSA, on the three facades not facing Renfrew Street, the great majority of the surfaces are solid uninterrupted masonry: on the east elevation (Dalhousie Street), a mere $8 \%$ of the facade is openings; on the west elevation (Scott Street) it is $19 \%$; and $10 \%$ on the south elevation. The blankness used to emphasise the sculptural quality of the 'Tower House' on the southwest corner.

Against this, the new Reid Building sits comfortably as a rather benign neighbour. It is deferential in its dumbness - a term used more than once to abuse its simplicity. But this dumbness, as Reyner Banham observed about James Stirling's History Faculty library, is more someone taking up or developing another language. Pace Serra and Adams on Reich. Pevsner favoured elegance over dumbness and loathed the History Faculty library which he described as 'anti-architecture', as actively ugly. He actually draws a parallel with the movement of antiart, an acknowledgement that Stirling's building is an example of an 'Architecture of Resistance' characterised by bloody mindedness and manifesting what Banham describes as 'dumb insolence': 'to get away with this architecture [...] in Cambridge requires more than derring-do: it requires the self confidence that comes from knowing what you are about, and it implies an attitude - against which (other) buildings appear "effete".'

In a prosaic reading of the new building's plan, there are five rectangles. Within the city, the standard feu or plot of Blythswood Hill is similarly defined by the cross walls - most plots in this part of the city are traditionally fifty feet wide, contrasting with, but redolent of, a New York tenement, traditionally $25 \mathrm{ft} \mathrm{x}$ 10oft - two in each 'block' of the Holl plan. Another feature reminiscent of the New York tenement, if we can continue this analogy, are the tight light wells driving light into the centre of the plans as exemplified in LaMotta's apartment in Scorsese's Raging Bull where they easily talk to people next door, or as in Coppola's Godfather 2. This imagery for the driven voids is reinforced when watching the building in use - particularly at the opening ceremony when bodies crowdedout the openings in a manner reminiscent of an old close in Edinburgh's old town or a Glasgow back court.

The retention of the old Victoria café structure as part of the Reid Building is of little value in my view. David Porter initiated some serious assessment of its limited value as a precursor to the competition. However, by introducing it into the Reid Building, it does link the building to the remainder of Renfrew Street beyond the adjacent Bourdon building and it defines the dimensions of the traditional plot in that part of the city, reinforcing the memory of that original Garnethill street pattern. Perhaps the finest achievement of that retention is to permit that small intervention that is the greatest joy in the building, the boiler plate steel staircase that links it into the Holl building. In its geometric unadorned crafted state, it is the one concession to overtly encapsulating the spirit of Mackintosh in this building, drawn from the detailing of the Art School library, and that is maybe all that is necessary to bridge the gap. To connect the seemingly less obvious empathies that exist between both buildings.

GORDON MURRAY Glasgow

Gordon Murray is Professor of Architecture at University of Strathclyde in Glasgow and a Partner in Ryder Architecture

\section{Illustration credits}

arq gratefully acknowledges:

Glasgow School of Art / Steven Holl

Architects, 3, 4

Royal Academy, photography by James Harris, 1, 2

Letters for publication should be sent to:

Adam Sharr

adam.sharr@newcastle.ac.uk

The Editors reserve the right to shorten letters 